\title{
INVESTIGATION OF LATE ANTIQUE BRICKS FROM ARCHAEOLOGICAL SITES OF CONTEMPORARY SERBIA AS A BASIS OF CONSERVATION WORKS
}

\author{
UDC 691.4:902.2(497.11)"652" (045)=20
}

\begin{abstract}
Ana Radivojević
University of Belgrade, Faculty of Architecture, 11000 Belgrade, Serbia and Montenegro

Abstract. Protection and revitalization of building heritage of the territory of contemporary Serbia includes numerous late classical archaeological sites. In spite of the efforts oriented to their adequate protection and presentation, the up-to-date conservation practice has faced various problems, particularly those related to the conservation of the brickwork. Problems especially emerge when the need for the new bricks arises, due to their different quality in comparison with those of historical ones. The problem is emphasized by the fact that the recent conservation process, practiced in this region, has not been followed by any qualitative analysis, either of historical or contemporary bricks. Therefore, the results of the recent investigation focused on characterization of late antique bricks from the region have been presented in this paper, seen in the context of conservation works.
\end{abstract}

Key words: bricks, conservation work, compatibility.

\section{INTRODUCTION}

Building heritage of contemporary Serbia may be seen in a variety of archaeological sites. The majority of these sites are the remains from the ancient Roman times, that is, late antiquity. Many of these monuments represent buildings or their parts that once belonged to important urban settlements, whose significance often exceeded the local limits.

In spite of numerous archaeological investigations, which, on one hand, indicated scientific curiosity for this historical period, and historical and architectural value of these remains on the other, the conservation treatments that followed the archaeological investigations have not always been successful and sufficient. As a result, degradation of building material occurred in many cases. This phenomenon is particularly obvious for bricks, which were one of the main building materials of the ancient times in the region. Although many efforts concerning practical conservation work have been made to find the

Received April 24, 2005 
right solution for this problem, none of them gave a successful result in a long term. The possible explanation for this situation could be found in the fact that up-to-date efforts relied only on skilfulness and experience of conservators, masons or brick manufacturers, without any qualitative investigation of the building material.

Due to the lack of knowledge about the quality of historical material from this region, i.e. bricks in this case, a thorough research, focussed on qualification of properties of late antique bricks, was initiated [5]. Several archaeological sites that were representative for their time (Sirmium, Viminacium, Naissus and Mediana, Felix Romuliana, Caričin Grad, Bregovina, Balajnac and Zlata) were consequently adequate to be the subject of this research. The obtained results offered the data regarding the quality of bricks for the first time. The results were discussed in the light of different settlements, typical chronological phases (IV and VI century), or late antiquity as a historical period in general.

The applicative value of these results is undoubtedly oriented towards practical conservation work in domain of protection of late antique archaeological sites. Therefore, the characteristics and problems of the conservation work that is practiced in Serbia, as well as aims and results of the research conducted on the late antique bricks, in the light of the conservation practice, will be discussed further on.

\section{UP-TO-DATE USE OF BRICKS IN CONSERVATION WORKS IN SERBIA}

Since brick was one of the main building materials of the late antiquity, consequently, in contemporary conservation work on the late antique remains there has often been a need for larger quantity of this material. Although we could say that the required quantity of bricks depended on the size of the building and on the type of planned conservation treatment, generally there is always a need for some extra brick, at least for a slight extension of height of remained walls for the purpose of protection of their top side. Regarding this fact, up-to-date conservation practice dealt with this problem in two different ways. One concerned the use of original brick that was found during excavations in the surrounding soil, while the other regarded production of new bricks for this purpose.

No matter which of the mentioned procedures has been applied, the present state of many archaeological sites requires sometimes urgent interventions, in order to prevent any further degradation that could be fatal for these ruins.

\subsection{Present condition of archaeological sites and remains}

The problems regarding condition of archaeological sites could be classified in two different types of causes: those regarding the applied conservation methods, or regarding the applied building materials for this purpose.

We could say that, in the first place, many problems are a consequence of an inappropriate protection and presentation policy that was applied in a particular case. These problems include the maintenance issue which is, unfortunately, very often lacking. Therefore, some very important archaeological sites that were properly conserved in the past, have almost disappeared from the ground nowadays. Another example regards a certain number of sites, which were left in the original condition, without any conservation treatment applied, which induced their degradation in this way. 
One may find the extreme example in the case of Bregovina. The site represents the VI century fortification, within which there was a basilica. The well-preserved remains of the building were discovered and properly conservated in early 1960's. However, left without the public affirmation, being far away from the main roads and in an environment where local people, instead of protecting their heritage, used these ruins as a storage of building materials, the site was doomed to its almost complete disappearance today (Figure 1).
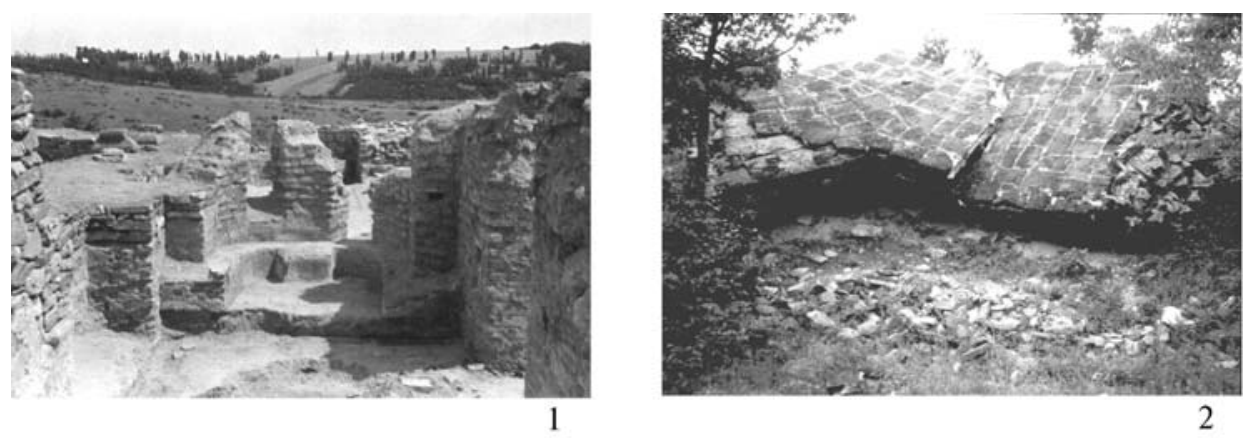

Fig. 1. Condition of the site of Bregovina in the time of conducted conservation works (1) and today (2)

When the question of the condition of the remains is treated at the level of building materials, in the case of brick we could say that the original, e.g. historical bricks prove to be more durable and resistant to environmental conditions than the new ones. Focused on the micro-environment of a material, which in case of a brickwork concerns the quality of a contact between a brick and a mortar, and having in mind the origin of a material (original or new one), we could distinguish three types of a contact:

- Between the original parts of a brickwork, e.g. original mortar and original brick,

- Between the original brick and new mortar, and

- Between the new brick and new mortar.

In respect to this, in the case of the analyzed late antique sites the applied conservation practice experienced different problems. The question of a quality of contact is, in case of the original parts, a matter of degree of their decay. Consequently, in the firm parts of the original structure, which did not suffer from any decay, the bond is, in most of the cases, strong. However, the application of new materials, especially the application of a new mortar, could cause a weak bond between the brickwork parts, e.g. mortar and brick (either original or new one). Furthermore, we could say that in certain cases a different type of salt crystallization appeared on new materials, especially on the new bricks for repair work (Figure 2). This could be explained by their incompatibility regarding the chemical contents. But even when the new brick did not have any problems with salts, its durability proved to be lower in comparison with the original bricks. 


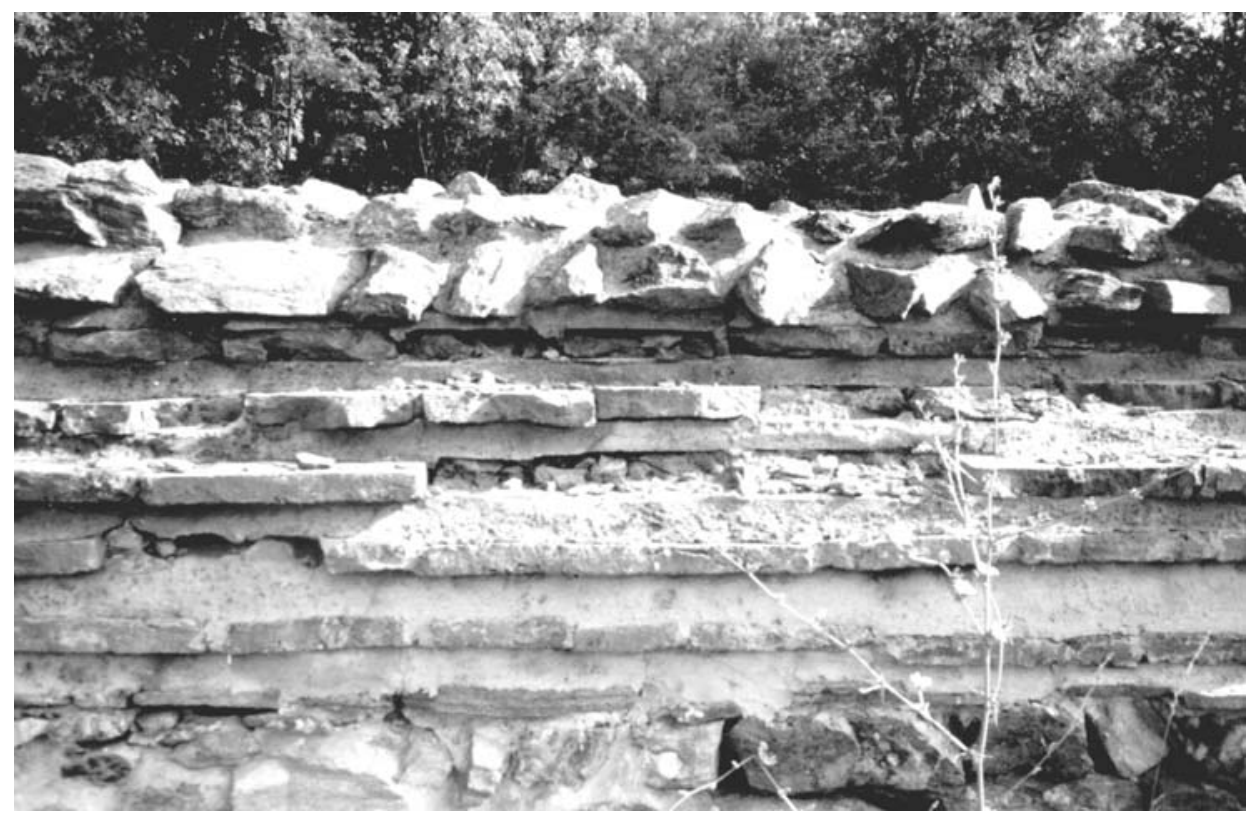

Fig. 2. Typical example of degradation - part of wall of a so-called double basilica from the archaeological site of Caričin Grad, extended with contemporary materials

\subsection{Up-to-date practice of production and application of new bricks in conservation works}

The research of the causes of such poor condition and durability of new bricks lead to the inspection of the up-to-date approach to a problem of production of bricks for repair conservation work. Hence, an inquiry was conducted among those Serbian architects-conservators who dealt with late antique archaeological sites in their conservation practice. The posed questions were focused on the matters of:

- type of buildings that were a subject of conservation work, as well as a present state of their preservation,

- applied procedures regarding the brick production for the purpose of conservation work, and

- control of: a) brick quality and b) their further behaviour in the building remains.

Summarized, obtained answers showed a dual nature of decay causes. Initially, a problem arises as a result of the fact that the archaeological remains are, by their nature, exposed to climatic causes of decay. This is the general conservation problem of any archaeological site anywhere in the world. However, we could stress that climate in Serbia is not favourable for archaeological remains due to extremely variable temperature in winter and summer period, followed with changes of air humidity, and frequent frost during the winter time.

On the other hand, another reason for such a bad condition of repaired brickwork was found and confirmed by those answers to the inquiry that explained the procedures applied to the brick production and further control of their quality. The way in which new 
bricks were produced ranged from the traditional brick manufactory, to the contemporary brick production that relies on the use of the semi-dry pressing procedure, or even to inventing the completely new, so called "concrete bricks" (Figure 3). These bricks were used in some cases as a replacement for the original clay material.

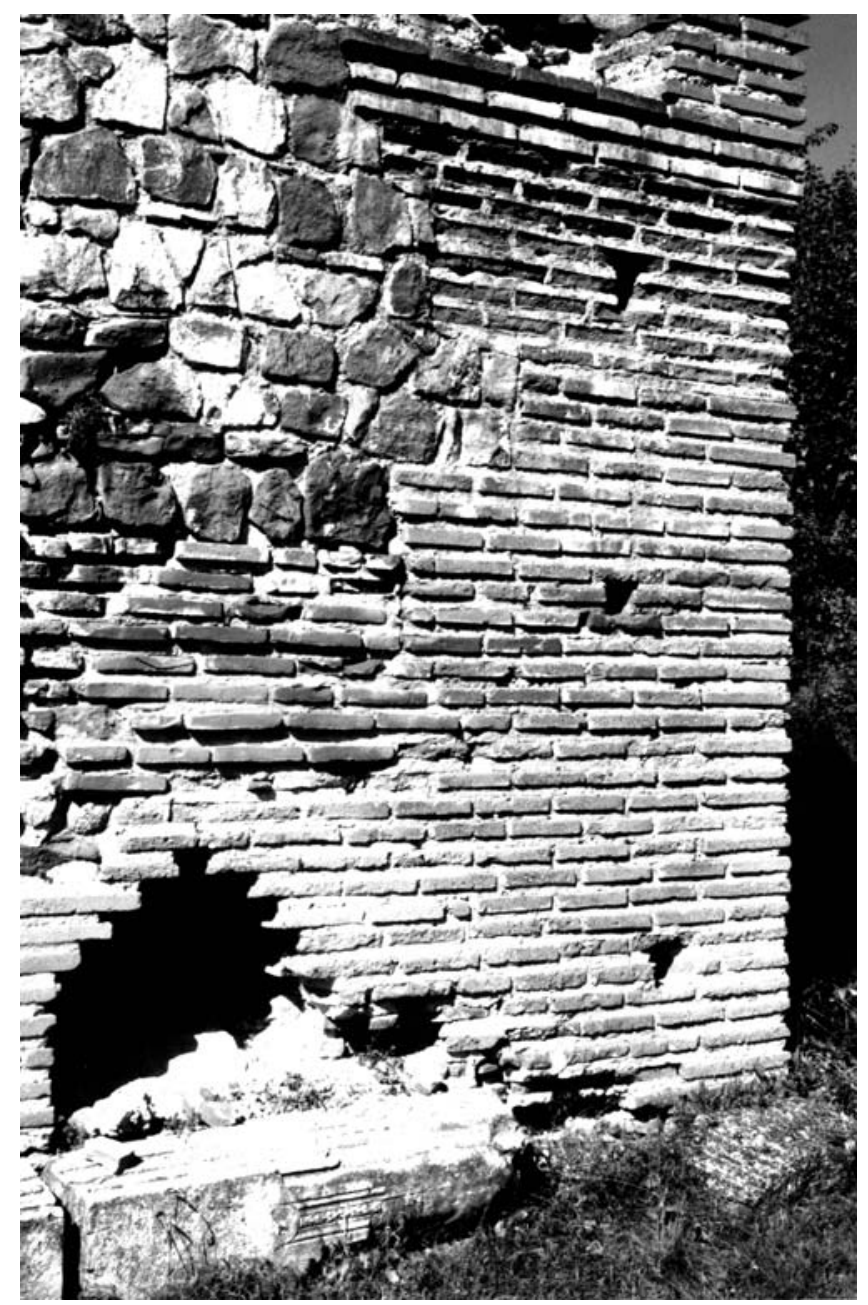

Fig. 3. Detail from the fortification of Gamzigrad (Felix Romuliana) where bricks produced in a different way were applied in different phases of conservation work

However, a conclusion may be drawn, that irrespective of the applied production procedure, the only things that were the subject of control in this process, referred to visual characteristics of bricks, e.g. their colour and size. Neither physical nor chemical properties of the new bricks were checked in any investigated case. 


\subsection{Necessary steps in a future process of conservation of historical brickwork}

Regarded in this light, the expressed problems proved to be a result of incomplete treatment of the problem itself. Therefore, the future conservation work should include investigation and control of required physical and chemical properties of bricks, and this should become a compulsory step in the conservation procedure.

This procedure itself is well known, and represents a process of creation of a so-called compatible building material [3]. Unfortunately, although the procedure itself was not unknown in its general parts to Serbian conservators, so far, it was not put into practice.

The development and application of compatible materials that should be conducted in the future, includes several important steps, which require a more active approach and cooperation between a variety of professionals. These steps could be summarized in three points:

- identification of properties of original building materials,

- identification of causes and mechanisms of decay, and

- definition of a "recipe" for creation and application of a new, compatible material, taking into account all environmental characteristics, characteristics of a raw material and technological demands that could be relevant for a particular case.

\section{RESEARCH CONDUCTED ON THE LATE ANTIQUE BRICKS}

Having in mind the previously expressed need for implementation of compatible materials in the conservation process, in case of late antique bricks, an identification of their properties has been done recently [5].

Induced by the significant differences in size and shape, and visual differences in quality of bricks from the beginning and the end of the time of late antiquity (IV and VI century), the conducted research had several objectives that were represented in a process of identification of brick properties. One of them was to define the average properties of bricks from the chosen sites in respect to the typical chronological periods and to confirm or deny the assumed differences of their quality. Another research that is more important for this particular work was focused to the application of these results in the light of conservation works. In both cases, this research was the first one ever conducted to such an extent, of any of the bricks from this region. Therefore, the choice of archaeological sites, as well as performed investigation program, were of great importance in the process of obtaining relevant results.

\subsection{Sampling and investigation process}

In order to obtain the most relevant data about the historical bricks from IV and VI century, a thorough choice of archaeological sites and buildings was made. This first step was to ensure that the bricks chosen were the true representatives of the typical chronological phases. Four different archaeological sites represented each chronological phase, while, in total, the research was conducted on 83 representative brick samples.

The set of analyses that were performed on these brick samples included three different types of investigation: morphological, physical and chemical (Table 1). The last type of analysis was conducted on a reduced number of samples. Therefore, these results could 
be used for limited purposes, but not for any conclusions regarding average brick properties. All of the noted analyses were performed on the samples that were cut to the size of $4 \times 4 \times 16 \mathrm{~cm}$. Previously, bricks or their pieces from which the samples were cut, were thoroughly observed and described.

Table 1 The scope of conducted investigations

\begin{tabular}{|c|c|c|c|c|c|c|c|c|c|c|c|c|c|c|c|c|c|c|}
\hline \multirow{5}{*}{ 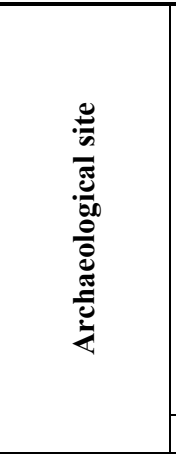 } & \multirow{4}{*}{\multicolumn{3}{|c|}{ 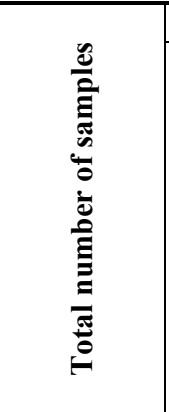 }} & \multicolumn{15}{|c|}{ Performed analysis } \\
\hline & & & & \multirow{4}{*}{ 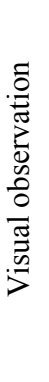 } & \multirow{4}{*}{ 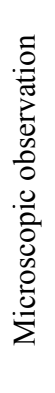 } & \multicolumn{2}{|c|}{ 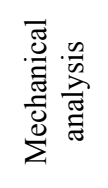 } & \multirow{4}{*}{ 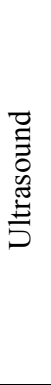 } & \multirow{4}{*}{$\begin{array}{l}\text { 离 } \\
0 \\
0 \\
0 \\
0\end{array}$} & \multirow{2}{*}{\multicolumn{6}{|c|}{ 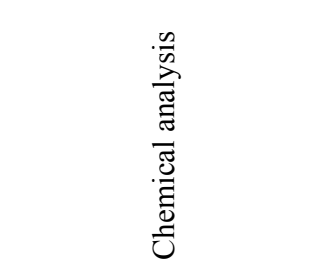 }} & \multirow{3}{*}{\multicolumn{3}{|c|}{ 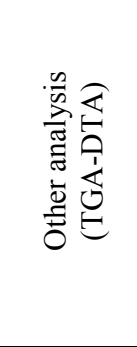 }} \\
\hline & & & & & & \multirow{3}{*}{ 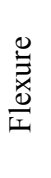 } & \multirow{3}{*}{ 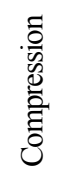 } & & & & & & & & & & & \\
\hline & & & & & & & & & & & Salt & & & xide & & & & \\
\hline & III & IV & $\mathrm{VI}$ & & & & & & & III & IV & $\mathrm{VI}$ & III & IV & $\mathrm{VI}$ & III & IV & $\mathrm{VI}$ \\
\hline \multirow{2}{*}{ Sirmium } & \multicolumn{3}{|c|}{6} & \multirow{2}{*}{6} & \multirow{2}{*}{6} & \multirow{2}{*}{6} & \multirow{2}{*}{6} & \multirow{2}{*}{6} & \multirow{2}{*}{6} & \multicolumn{3}{|c|}{2} & \multicolumn{3}{|c|}{1} & \multicolumn{3}{|c|}{1} \\
\hline & 2 & 4 & 1 & & & & & & & 1 & 1 & & 1 & 1 & 1 & 1 & 1 & 1 \\
\hline & \multicolumn{3}{|c|}{7} & \multirow{2}{*}{7} & \multirow{2}{*}{7} & \multirow{2}{*}{7} & \multirow{2}{*}{7} & 7 & 7 & & 4 & & & 1 & & & 1 & \\
\hline Viminacium & 1 & 5 & 1 & & & & & 1 & 1 & 1 & 2 & 1 & I & 1 & 1 & & 1 & \\
\hline & & 15 & & 15 & 15 & 15 & 15 & 15 & $15->$ & & 6 & & & 1 & & & 1 & \\
\hline Nalssus & 1 & 13 & 2 & 15 & 15 & 15 & 15 & 15 & 15 & 1 & 5 & 1 & I & 1 & 1 & & 1 & \\
\hline Felix & & 10 & & 10 & 10 & 10 & 10 & 10 & 10 & & 3 & & & 1 & & & 1 & \\
\hline Romuliana & 1 & 10 & 1 & 10 & 10 & 10 & 10 & 10 & 10 & 1 & 3 & 1 & 1 & 1 & 1 & & 1 & \\
\hline Poloing & & 3 & & 3 & 3 & 3 & 3 & 3 & 3 & & 1 & & & 1 & & & 1 & \\
\hline Balajnac & 1 & 1 & 3 & 3 & 3 & 3 & 3 & 3 & 3 & 1 & 1 & 1 & 1 & 1 & 1 & & 1 & \\
\hline Zlata & & 9 & & 9 & 9 & 9 & 9 & 9 & 9 & & 3 & & & 1 & & & & \\
\hline Zlata & 1 & 1 & 9 & 9 & 9 & 9 & 9 & 9 & 9 & 1 & 1 & 3 & 1 & 1 & 1 & & 1 & \\
\hline Breogyina & & 10 & & 10 & 10 & 10 & 10 & 10 & 10 & & 2 & & & 1 & & & 1 & \\
\hline Dregovind & 1 & 1 & 10 & 10 & 10 & 10 & 10 & 10 & 10 & 1 & 1 & 2 & 1 & 1 & 1 & 1 & 1 & 1 \\
\hline & & 23 & & & & & & & & & 5 & & & 1 & & & 1 & \\
\hline Caricin Grad & 1 & 1 & 23 & 23 & 23 & 23 & 23 & 23 & 23 & 1 & 1 & 5 & 1 & 1 & 1 & 1 & 1 & 1 \\
\hline & & 83 & & 83 & 83 & 83 & 83 & $83+2$ & $83+2$ & & 26 & & & 8 & & & 3 & \\
\hline Fotal & 3 & 32 & 48 & 03 & 03 & 03 & 03 & 03 & 03 & 2 & 11 & 13 & 1 & 4 & 4 & 1 & 1 & 2 \\
\hline
\end{tabular}

\subsection{Relevant properties of IV and VI century bricks}

The scope of conducted research provided various and numerous information about the late antique bricks and their quality. Summarized and accepted as average properties of IV and VI century bricks from the analyzed region, they have been systematized into four specific groups of characteristics that could be described as: technological, dimensional, other morphological and physical.

On the other hand, in respect to the up-to-date experience, properties that should be harmonized between historical and compatible materials exclude in a great deal the technological ones, since the notion of compatibility does not comprise the production proc- 
ess itself. However, the obtained quality of a new material, which is relevant for its proper application should be the main concern. This actually means compatibility regarding:

- visual characteristics, especially regarding colour and surface characteristics,

- mechanical strength, especially flexural and compressive,

- porosity,

- elasticity and deformability of a material,

- thermal dilatation and

- density.

Therefore, those properties that correspond to the requirements of future compatible bricks are presented in Table 2 .

Table 2. Comparative review of relevant properties of analyzed IV and VI century bricks

\begin{tabular}{|l|l|l|}
\hline $\begin{array}{l}\text { Group of } \\
\text { properties }\end{array}$ & \multicolumn{1}{|c|}{ IV century bricks } & \multicolumn{1}{|c|}{ VI century bricks } \\
\hline Dimensional & $\begin{array}{l}\text { usually having shape of elongated } \\
\text { rectangle; } \\
\text { width up to } 30 \mathrm{~cm}, \text { length } 40 \mathrm{~cm} \text { and more, } \\
\text { average thickness } 4-6 \mathrm{~cm}, \text { but as a local } \\
\text { characteristics, thickness could be } \\
\text { either thinner or thicker; }\end{array}$ & $\begin{array}{l}\text { great variations in sizes and shapes that } \\
\text { differ from elongated rectangles, square } \\
\text { rectangles, up to square formats; } \\
\text { maximal dimension of bricks up to } \\
40 \mathrm{~cm} ; \\
\text { average thickness 4-6cm; }\end{array}$ \\
\hline $\begin{array}{l}\text { Oniform colour; } \\
\text { Well compacted; } \\
\text { mostly smooth and semi-smooth; } \\
\text { mo significant pathological indications; } \\
\text { without significant voids and crack in a a } \\
\text { macrostructure; } \\
\text { frequent presence of grains of dry clay, } \\
\text { philosilicates and grains of calcite; } ;\end{array}$ & $\begin{array}{l}\text { frequent presence of polichromy; } \\
\text { well compacted; } \\
\text { mostly rough and semi-rough; } \\
\text { frequent indications of efflorescence; } \\
\text { large pores, voids and cracks; } \\
\text { frequent presence of sand in clay, as well } \\
\text { as large grains of aggregate; frequent } \\
\text { presence of philocilicates; }\end{array}$ \\
\hline $\begin{array}{l}\text { Physical } \\
\text { (average } \\
\text { values) }\end{array}$ & $\begin{array}{l}\text { porosity: } 19,35 \% \\
\text { density: } 1,78 \mathrm{~g} / \mathrm{cm}^{3} \\
\text { module of elasticity: } 124362,6 \mathrm{~kg} / \mathrm{cm}^{2} \\
\text { compr. strength: } 185,5 \mathrm{~kg} / \mathrm{cm}^{2} \\
\text { flexural strength: } 75,8 \mathrm{~kg} / \mathrm{cm}^{2}\end{array}$ & $\begin{array}{l}\text { porosity: } 18,06 \% \\
\text { density: } 1,3 \mathrm{~g} / \mathrm{cm}^{3} \\
\text { module of elasticity: } 59200,9 \mathrm{~kg} / \mathrm{cm}^{2} \\
\text { compr. strength: } 100,5 \mathrm{~kg} / \mathrm{cm}^{2} \\
\text { flexural strength: } 29,1 \mathrm{~kg} / \mathrm{cm}^{2}\end{array}$ \\
\hline
\end{tabular}

\section{CONCLUSION REMARKS}

Summarizing two poles of the analysed problem, it could be said that, on one hand, the evident problems of contemporary conservation practice in Serbia were clearly defined and specified, while, on the other, the previous research, conducted on the late antique bricks, offered for the first time the exact data about the quality of these historical bricks.

The already expressed tendency to find a good match regarding visual characteristics of the new bricks for repair work could now be fulfilled with requirements regarding their physical properties that are presented in Table 3 . In respect to this, the differences that were distinguished between IV and VI century bricks could be considered the permissive limits in respect to the values of certain properties of future compatible bricks, regarding the required dimensions, e.g. format of this building element, in each particular case. 
Table 3. Values of typical physical properties of IV and VI century bricks and suggested value limits regarding their compatible bricks

\begin{tabular}{|l|c|c|c|}
\hline Type of bricks & $\begin{array}{c}\text { Porosity } \\
{[\%]}\end{array}$ & $\begin{array}{c}\text { Density } \\
{\left[\mathrm{g} / \mathrm{cm}^{3}\right]}\end{array}$ & $\begin{array}{c}\text { Compressive strength } \\
{\left[\mathrm{kg} / \mathrm{cm}^{2}\right]}\end{array}$ \\
\hline IV century & 19,35 & 1,78 & 185,5 \\
\hline VI century & 18,06 & 1,83 & 100,5 \\
\hline Compatible bricks & $17-20$ & $1,70-1,90$ & $90-195$ \\
\hline
\end{tabular}

Hence, the problems that followed conservation work, and which were in most part caused by the lack of exact knowledge about properties of building material, both historical and new ones, can finally be overcome, at least when the late antique bricks were concerned.

\section{REFERENCES}

1. Fielden M. B.: Conservation of Historic Buildings, Butterworth - Heinemann Ltd., Oxford, 1994.

2. Karaveziroglou, M., Papayianni I., Penelis, G.: "Criteria for Selecting Materials for Repair Brick Masonry", Structural Conservation of Stone Masonry, ICCROM, Rome, 1990, pp. 335-41.

3. Papayianni, I.: "A holistic way of studying mortars and bricks of ancient masonries for manufacturing compatible repair materials", Proc. $4^{\text {th }}$ Symposium of the Conservation of Monuments in the Mediterranean. Rhodes, 1997, pp. 265-74.

4. Papayianni, I., Astrinidou, P., eds.: Materials for Consolidation and Restoration of Monuments and Historical Buildings: Reading, Interpreting and Recovering the Knowledge of Traditional Materials, Museum of Byzantine Culture, Thessaloniki, 1995.

5. Radivojević, A.: Opeke kasnoantičkih građevina rimskih centralnobalkanskih provincija, [Bricks of Late Antique Buildings in the Roman Provinces of the Central Balkans] Ph.D. thesis, Faculty of Architecture, University of Belgrade, 2003.

6. Radivojević, A., Dervissis, D.: "Production and Testing of Bricks for Repair Work", Proc. $2^{\text {nd }}$ International Congress in Studies in Ancient Structures, Istanbul, 2001, pp. 581-8.

\section{ISTRAŽIVANJE KASNOANTIČKIH OPEKA SA ARHEOLOŠKIH LOKALITETA U DANAŠNJOJ SRBIJI KAO OSNOVA ZA KONZERVATORSKE RADOVE}

\section{Ana Radivojević}

Zaštita i revitalizacija graditeljskog nasleđa sa područja današnje Srbije obuhvata brojne kasnoantičke arheološke lokalitete. Uprkos nastojanjima ka njihovoj adekvatnoj zaštiti i prezentaciji, dosadašnja konzervatorska praksa je bila suočena sa brojnim problemima, a posebno onim koji se tiču konzervacije zidanih konstrukcija od opeke. Problem biva posebno izražen u slučajevima kada postoji potreba za novim opekama, imajući u vidu razlike u kvalitetu današnjih opeka u poređenju sa istorijskim. Dodatno ga naglašava činjenica da dosadašnji postupci konzervacije kakvi su bili primenjivani na ovom području, nisu bivali propraćeni bilo kakvim kvalitativnim analizama ni istorijskih ni savremenih opeka. Stoga su u ovom radu prikazani rezultati skorašnjeg istraživanja koje je bilo sprovedeno u cilju određivanja karakteristika kasnoantičkih opeka sa posmatranog područja, posmatrani u svetlu potreba postupka konzervacije. 